\title{
Impact of socioeconomic status on patient experience on quality of care for ambulatory healthcare services in tertiary hospitals in Southeast Nigeria
}

Henry E. Aloh ${ }^{1,2^{*}}$ (D, Obinna E. Onwujekwe ${ }^{2}$, Obianuju G. Aloh ${ }^{3}$, ljeoma L. Okoronkwo ${ }^{2}$ and Chijioke Joel Nweke

\begin{abstract}
Background: To determine how socioeconomic factors, such as level of education and employment status, affect patient experiences on quality of care for ambulatory healthcare services in teaching hospitals in southeast Nigeria.

Methods: The study is of a cross-sectional design and exit poll was used to collect its data. A pre-tested structured questionnaire was administered to clients accessing care in the outpatient departments of three tertiary hospitals in Nigeria. The assessment of patient experiences for quality of care was based on five (5) domains of care: waiting time; environment of the outpatient department; quality of doctor's care; quality of care by nurses/other health workers; and responsiveness of care. In addition, the overall quality of care was assessed.

Results: The mean rating of patient experience for quality of care for ambulatory healthcare services (outpatients' care) was $74.31 \pm 0.32 \%$. Moderate differences were observed between the hospitals assessed for various levels of patients' care, especially for waiting time, quality of doctors' care and overall quality of care. Employment status was a statistically significant $(p \leq 0.05)$ determinant of overall patient experience rating for quality of care, while the level of patient's education was an influence on the perception of waiting by the patients and their rating of care from nurses/other healthcare providers (apart from medical doctors).

Conclusion: The study showed that educational and employment status (measures of socioeconomic status) of patients determined how patients receiving ambulatory (outpatient) healthcare services perceived the quality of care in the hospitals. Hence, in order to ensure equity, there is need to institutionalize patient-centered care, while full consideration is given to the patients' socioeconomic status.
\end{abstract}

Keywords: Quality of care, Patient experience, Socioeconomic status, Hospitals, Nigeria

\footnotetext{
* Correspondence: henryealoh@gmail.com

${ }^{1}$ Health Economics and Policy Research Unit, Department of Health Services,

Alex Ekwueme Federal University Ndufu-Alike Ikwo, Ikwo, Ebonyi State,

Nigeria

${ }^{2}$ Department of Health Administration \& Management, Faculty of Health

Sciences, College of Medicine, University of Nigeria, Enugu Campus, Enugu,

Nigeria

Full list of author information is available at the end of the article
}

(c) The Author(s). 2020 Open Access This article is licensed under a Creative Commons Attribution 4.0 International License, which permits use, sharing, adaptation, distribution and reproduction in any medium or format, as long as you give appropriate credit to the original author(s) and the source, provide a link to the Creative Commons licence, and indicate if changes were made. The images or other third party material in this article are included in the article's Creative Commons licence, unless indicated otherwise in a credit line to the material. If material is not included in the article's Creative Commons licence and your intended use is not permitted by statutory regulation or exceeds the permitted use, you will need to obtain permission directly from the copyright holder. To view a copy of this licence, visit http://creativecommons.org/licenses/by/4.0/ The Creative Commons Public Domain Dedication waiver (http://creativecommons.org/publicdomain/zero/1.0/) applies to the data made available in this article, unless otherwise stated in a credit line to the data. 


\section{Background}

People's state of health and the manner in which it is cared for is indeed regarded as a very important component of economic development of any country $[1,2]$. The health sector targets often relate to traditional hospital functions such as diagnosis, outpatient treatment and inpatient care. Outpatient services are those hospital services that do not require an overnight stay and may include care such as diagnostic tests, prescriptions or simple treatment/procedures [3]. These services are offered on ambulatory basis, and they account for the majority of patient-medical professional encounters than any other hospital services (approximately four times than that of inpatients).

Few studies have examined patient experience for quality of care in resource-scarce environment like subSaharan African countries such as Nigeria. Measurement of quality can be very useful to stakeholders who choose between different health care providers, and to the policy makers who strive to enunciate better health policies [4]. Standardized surveys of patients and relatives can reliably measure hospital performance by assessing patients' experience and outcomes of treatment. Patient experience (PE) evaluates what happens at the point of contact between the patient, the practice, and the provider [5]. It captures health system responsiveness, including the manner and environment in which people are treated when they seek healthcare [6]. It also includes sufficient information and education of the patient, coordination of care, physical comfort, emotional support, respect for patient preferences, involvement of family and friends [4].

Patient experience is not the same as perceived quality which is predominantly a cognitive assessment of what happened and how it happened [7]. It is also different from patient satisfaction which is referred to as patients' emotion, feelings and their perception of delivered healthcare service [8]. Patient satisfaction is regarded as the degree of congruency between patient expectations of ideal care and their perception of the real care received [9] and it tends to seek subjective responses from patients. In contrast, PE asks patients to give factual responses to questions about what did or did not happen during episode of care.

A major challenge to measuring healthcare quality in low- and middle-income countries (LMICs) was highlighted by a study carried out by Dunsch et al., (2017) on more than 2200 patients in Nigeria using positive and negative framed satisfaction statements [10]. The result showed that patient satisfaction measurements are deeply sensitive to the framing of the questions and hence the need to adapt patient experience that avoids a short-laced response of agree/disagree and yes/no questions. It is believed that PE survey questionnaires that are well designed and appropriately administered can provide a robust measure of quality of care and reliably measure hospital performance against explicit standardization $[11,12]$. Several studies have been carried out on quality of healthcare services especially in developed countries; quite a handful in African region and very few in sub-Saharan African countries like Nigeria. Many reviewed literatures on quality of healthcare show that waiting time is one of the most important indicators or variables of healthcare quality. One of such is a cross sectional observational study by the Patels (2017) on waiting time and outpatient satisfaction at Gujarat medical education research society hospital India, using 135patients from the outpatient department (OPD) [13]. A cross sectional survey of nurses $(33,659)$ and patients $(11,318)$ in 12 countries in Europe and the United States on patient safety, satisfaction and quality of hospital care, using hierarchical modelling and robust logistic regression, showed that deficits in hospital care quality were common in all countries [14]. Mejabi et al., (2008) in their work on dimensions of hospital service quality in Nigeria, as published in European Journal of Social Sciences, used probability and quota sampling methods on 6 service points (medical outpatient clinic, surgical outpatient clinic, medical male ward, medical female ward, surgery male ward and surgery female ward) and applied correlation matrices/factor analysis to evaluate quality of healthcare in two Nigeria teaching hospitals. Their findings show that eight (8) dimensions of resource availability, quality of care, condition of the clinic/ward, condition of the facility, quality of food, attitude of doctors and nurses, attitude of non-medical staff and waiting time adequately describe service quality phenomenon in Nigerian hospital setting [15].

The aim of the present study is to evaluate patients' experience (PE) on quality of care among clients accessing ambulatory (outpatients) healthcare services in teaching hospitals, Southeast Nigeria.

There is paucity of knowledge on the effects of socioeconomic variables on PE for ambulatory healthcare services in hospitals. The present study focused on how socio-economic factors represented, in the context of this study, by level of education and employment status of outpatients affect PE on quality of care. Level of education and employment status were used because the two are the commonest socio-economic parameters that are used by the teaching hospitals in Nigeria when disaggregating socio-economic status of their patients.

\section{Methods}

The study design was a cross-sectional exit survey. Three (3) tertiary hospitals were randomly selected from seven (7) teaching hospitals in Southeast, Nigeria. The study population was 7847 patients, which was the projected outpatients flow for the 3 hospitals over a period 
of 3 months the data collection lasted. The hospitals are: Enugu State University Teaching Hospital (ESUTH), University of Nigeria Teaching Hospital (UNTH) and Federal Teaching Hospital Abakaliki (FETHA).

The sample size was determined using a formula for calculating required sample size for a patient population of less than 10,000 persons. $N_{f}=n / 1+(n / N)$; $N$ is average number of target population. Value of $\mathrm{n}$ was calculated using: $n=\mathrm{Z}^{2} \mathrm{pq} / \mathrm{d}^{2}$ as the formula [16]. Where $\mathrm{n}$ is minimum sample size required, $\mathrm{Z}$ is normal standard deviation at $95 \%$ confidence level and is 1.96 , $p$ is prevalence of the factor under study (in this case the outpatients) and from previous studies it is $84 \%(0.84)$ for outpatients [17].

A pre-tested structured patient experience questionnaire (PEQ) with scores assigned to the questions was developed and used for this study. The PEQ is designed to elicit actual experiences, ranging from the duration of hospital's waiting time to the environmental condition of the outpatient department, the quality of care rendered by the doctors and other health workers, the responsiveness of care and indeed the patient's overall rating of his experience [18]. The study generated and attached relative weights to each question as an indirect measure of the quality of ambulatory healthcare services. This was based on plausible measurements from previous studies that were adopted for the context of the study area [1820]. The weights in the present study were represented by scores, ranging from zero to ten $(0-10)$.

The questionnaire was pre-tested in a secondary level hospital that is located within the same geographical region, using about $10 \%$ of the sample size. The instrument was then revised for language and better understanding. Hence, there was no obvious problem with the respondents comprehending the questions and providing plausible answers to the questions. A reliability test for the questionnaire was carried out for internal and external consistency using Cronbach's alpha test and this gave Cronbach's alpha coefficient of 0.632 (i.e. $>0.5$ ), showing that the questionnaire was consistent and therefore reliable. A total of 422 questionnaires were administered to respondents (outpatients) in the teaching hospitals by well-trained interviewers. The responses were elicited without patient's identifier after a written consent were obtained from respondents $[18,20]$.

The data were analyzed using statistical methods such as Z-test and ANOVA to examine mean differences, and Chi-square/Log Linear association tools to compare the relationship between PE variables with level of education and employment status.

\section{Results}

Out of the 422 questionnaires that were administered a total of 408 were fully responded to. This represents a response rate of $96.7 \%$. The study results show that $50.7 \%$ of the respondents were male, whilst $49.3 \%$ were female. Majority $(73 \%)$ of the patients were within active age range of $18-65$ years. About $24 \%$ were above 65 years and $2.9 \%$ were below 18 years of age. It was found that $40.7 \%$ of the respondents had university education and $25.2 \%$ had high school education, whilst the remaining $34.1 \%$ had either primary school education or no formal education. Less than half (about 41.7\%) were employed, while $28.2 \%$ were unemployed and $18.1 \%$ retirees that were no longer economically active. Table 1 also shows that slight majority (51\%) of the patients received healthcare services at the surgical outpatient department (SOPD), while $49 \%$ were cared for in medical outpatient department (MOPD).

Table 2 shows that there were significant statistical differences $(p \leq 0.05)$ among hospitals for mean patient experience (PE) scores on waiting time, quality of doctors' care and that of overall rating. FETHA had the highest mean PE score for quality of doctor's care $(43.89 \pm 7.04)$ and for overall PE rating (76.46 $\pm 11.08 \%)$, UNTH had the best score for waiting time PE score (11.32 \pm 5.73$)$.

Table 3 disaggregates the healthcare services into medical and surgical, and compared the differences in their mean PE scores, within and between the hospitals. FETHA's MOPD had mean PE score of $27.22 \pm 0.43$ points for its environment, better than that of its SOPD which had mean PE score of $25.36 \pm 0.52$ points. FETHA's MOPD overall PE rating was $78.37 \pm 1.14 \%$ and significantly higher than that of SOPD (74.85 \pm 1.29). Similarly, in ESUTH the MOPD services were significantly $(p \leq 0.05)$ better than those of SOPD for quality of doctor's care, quality of care by nurses/other health professionals, as well as for overall rating. Only UNTH's SOPD overall PE rating of $76.96 \pm 1.51 \%$ was significantly $(\mathrm{p} \leq 0.05)$ better than that of its MOPD $(68.43 \pm 1.58 \%)$.

Table 4 shows that higher proportion $(61.1 \%)$ of outpatients without a formal education had mean PE score of more than 10 points for waiting time, compared to $34.3 \%$ of outpatients with university education and $41.7 \%$ of those with high school education. The result shows significant association between PE scores on waiting time and level of education. This was not so for PE score on OPD environment, quality of doctors' care and responsiveness of care for outpatients (as shown in Table 4). With quality of care by nurses/other care givers, the result show significant $(p \leq 0.05)$ association with educational status. Again, larger proportion of outpatient without formal education (85.7\%) scored this domain high compared to $68.6 \%$ of outpatients with university education. In addition, the result shows that employment status only had significant $(\mathrm{p} \leq 0.05)$ association with the overall PE rating; about $75.7 \%$ of retirees 
Table 1 Demography and socioeconomic status of outpatients

\begin{tabular}{|c|c|c|c|c|c|}
\hline \multirow[t]{2}{*}{ Variable } & \multirow[t]{2}{*}{ Categories } & \multicolumn{4}{|l|}{ Hospital } \\
\hline & & FETHA & ESUTH & UNTH & Total \\
\hline \multirow[t]{2}{*}{ Sex } & Male & $87(55.1)$ & $67(49.3)$ & $53(46.5)$ & $207(50.7)$ \\
\hline & Female & $71(44.9)$ & $69(50.7)$ & $61(53.5)$ & $201(49.3)$ \\
\hline \multirow[t]{3}{*}{ Marital Status } & Married & 110(69.6) & $98(72.1)$ & $71(62.3)$ & $279(68.4)$ \\
\hline & Not Married & $41(25.9)$ & $32(23.5)$ & $40(35.1)$ & $113(27.7)$ \\
\hline & Others & $7(4.4)$ & $6(4.4)$ & $3(2.6)$ & $16(3.9)$ \\
\hline \multirow[t]{3}{*}{ Age (Years) } & $<=18$ & $6(3.8)$ & $2(1.5)$ & $4(3.5)$ & $12(2.9)$ \\
\hline & $19-64$ & $112(70.9)$ & $96(70.6)$ & $90(78.9)$ & 298(73) \\
\hline & $65+$ & $40(25.3)$ & $38(27.9)$ & $20(17.5)$ & $98(24)$ \\
\hline \multicolumn{6}{|l|}{ SES } \\
\hline \multirow[t]{4}{*}{ Level of Education } & No Formal Education & $23(14.6)$ & $15(11)$ & $16(14)$ & $54(13.2)$ \\
\hline & Primary Education & $36(22.8)$ & $26(19.1)$ & $23(20.2)$ & $85(20.8)$ \\
\hline & Secondary Education & $50(31.6)$ & $29(21.3)$ & $24(21.1)$ & $103(25.2)$ \\
\hline & University Education & $49(31)$ & $66(48.5)$ & $51(44.7)$ & $166(40.7)$ \\
\hline \multirow[t]{5}{*}{ Employment Status } & Employed & $68(43)$ & $56(41.2)$ & $46(40.4)$ & $170(41.7)$ \\
\hline & Not Employed & $37(23.4)$ & $34(25)$ & $44(38.6)$ & $115(28.2)$ \\
\hline & Student & $22(13.9)$ & $13(9.6)$ & $14(12.3)$ & $49(12)$ \\
\hline & Retired & $31(19.6)$ & $33(24.3)$ & $10(8.8)$ & 74(18.1) \\
\hline & Total & $158(100)$ & $136(100)$ & $114(100)$ & $408(100)$ \\
\hline
\end{tabular}

The figures in the bracket, (), are \% along the column

and $64.7 \%$ of employed outpatients recorded higher overall PE rating in the hospitals studied. Students and the un-employed had least overall PE rating.

\section{Discussion}

The present study evaluated how outpatients of two different socioeconomic groups (educational and employment status) rate their experience in respect to various domains of care at Teaching hospitals in Southeast Nigeria. The study is an attempt to know how patient experience can serve as metric for health industry competition and differentiation, since it reflects quality of care from the patient's perspective [21]. The study confirms that measurement of patient experience is an important aspect of evaluation of healthcare services; and it provides an opportunity to improve care, meet patients' expectations, enhance strategic decision making, as well as effectively manage and monitor health care performance [21]. These are vital because there is no doubt that in the public eye, hospitals will continue to be the 'face' of the health system, and upon it the public assesses the quality of services provided [22]. Moreover, there is this emerging consensus that patient experience is a fundamental aspect of provider quality [23].

An inference from the findings is that UNTH had the shortest waiting time because patients spent less time waiting for services from doctors or other care givers. The other hospitals could learn from what UNTH is doing right and apply the same procedures in their

Table 2 Analysis of mean difference for patient's experience variables

\begin{tabular}{llllll}
\hline Variable & Hospital & & & & \\
\cline { 2 - 6 } & FETHA & ESUTH & UNTH & p-value & Remark \\
\hline Waiting Time & $10.56^{\mathrm{b}} \pm 4.96$ & $7.67^{\mathrm{a}} \pm 4.23$ & $11.32^{\mathrm{b}} \pm 5.73$ & 0.000 & Significant \\
OPD Environment & $26.21^{\mathrm{a}} \pm 4.42$ & $26.64^{\mathrm{a}} \pm 4.95$ & $27.09^{\mathrm{a}} \pm 4.10$ & 0.285 & Not Significant \\
Quality of Doctors Services & $43.89^{\mathrm{a}} \pm 7.04$ & $41.63^{\mathrm{b}} \pm 9.23$ & $38.66^{\mathrm{a}} \pm 9.74$ & 0.000 & Significant \\
Quality of care by Nurses/Other Medical Staff & $22.04^{\mathrm{a}} \pm 7.23$ & $19.89^{\mathrm{a}} \pm 6.60$ & $19.95^{\mathrm{a}} \pm 7.67$ & 0.172 & Not Significant \\
Responsiveness & $48.83^{\mathrm{a}} \pm 13.38$ & $51.07^{\mathrm{a}} \pm 10.86$ & $48.82^{\mathrm{a}} \pm 15.93$ & 0.282 & Not Significant \\
Overall Quality Rating (\%) & $76.46^{\mathrm{b}} \pm 11.08$ & $72.90^{\mathrm{a}} \pm 11.89$ & $73.00^{\mathrm{a}} \pm 12.39$ & 0.014 & Significant \\
\hline
\end{tabular}

Values are mean \pm Standard Deviation. Mean values along the row with different alphabetical superscript indicates a significant different 
Table 3 Analysis of mean difference for patient's experience variables scores among outpatients, along type of care (surgical and medical)

\begin{tabular}{|c|c|c|c|c|c|c|c|}
\hline \multirow[t]{2}{*}{ Variable } & \multirow{2}{*}{$\begin{array}{l}\text { Service } \\
\text { Type }\end{array}$} & \multicolumn{3}{|l|}{ Hospital } & \multirow{2}{*}{$\begin{array}{l}\boldsymbol{P} \text { - } \\
\text { value }\end{array}$} & \multirow[t]{2}{*}{ Remark } & \multirow[t]{2}{*}{ Overall } \\
\hline & & $\overline{\text { FETHA }}$ & ESUTH & UNTH & & & \\
\hline \multirow[t]{3}{*}{ Waiting Time } & Medical & $11.0^{\mathrm{b}} \pm 0.53$ & $7.4^{a} \pm 0.47$ & $11.67^{\mathrm{a}} \pm 0.91$ & 0.000 & Significant & $9.75^{a} \pm 0.38$ \\
\hline & Surgical & $10.18^{b} \pm 0.58$ & $8.0^{\mathrm{a}} \pm 0.56$ & $11.31^{\mathrm{b}} \pm 0.62$ & 0.001 & Significant & $9.88^{\mathrm{a}} \pm 0.35$ \\
\hline & $p$-value & 0.290 & 0.417 & 0.749 & & & 0.801 \\
\hline \multirow[t]{3}{*}{ OPD Environment } & Medical & $27.22^{\mathrm{a}} \pm 0.43$ & $26.44^{\mathrm{a}} \pm 0.52$ & $25.85^{\mathrm{a}} \pm 0.55$ & 0.170 & Insignificant & $26.57^{\mathrm{a}} \pm 0.29$ \\
\hline & Surgical & $25.36^{\mathrm{a}} \pm 0.52$ & $26.89^{b} \pm 0.70$ & $28.16^{b} \pm 0.498$ & 0.002 & Significant & $26.63^{a} \pm 0.34$ \\
\hline & $p$-value & $0.007^{*}$ & 0.611 & $0.002^{*}$ & & & 0.885 \\
\hline \multirow[t]{3}{*}{ Quality of Doctors' care or Services } & Medical & $44.63^{b} \pm 0.68$ & $43.75^{b} \pm 0.86$ & $35.25^{\mathrm{a}} \pm 1.60$ & 0.000 & Significant & $41.8^{\mathrm{a}} \pm 0.57$ \\
\hline & Surgical & $43.27^{\mathrm{a}} \pm 0.85$ & $39.03^{\mathrm{a}} \pm 1.34$ & $41.62^{\mathrm{a}} \pm 1.90$ & 0.028 & Significant & $41.54^{\mathrm{a}} \pm 0.66$ \\
\hline & $p$-value & 0.216 & $0.004^{*}$ & $0.026^{*}$ & & & 0.761 \\
\hline \multirow[t]{3}{*}{ Quality of care or Services by Other Medical Staff } & Medical & $22.71^{\mathrm{a}} \pm 1.17$ & $22.4^{\mathrm{a}} \pm 1.13$ & $19.23^{\mathrm{a}} \pm 1.63$ & 0.142 & Insignificant & $21.62^{\mathrm{a}} \pm 0.78$ \\
\hline & Surgical & $21.64^{\mathrm{b}} \pm 1.01$ & $16.47^{\mathrm{a}} \pm 1.81$ & $20.88^{\mathrm{b}} \pm 1.90$ & 0.065 & Insignificant & $20.60^{a} \pm 0.82$ \\
\hline & $p$-value & 0.49 & $0.010^{*}$ & 0.513 & & & 0.371 \\
\hline \multirow[t]{3}{*}{ Responsiveness } & Medical & $50.00^{b} \pm 1.29$ & $50.53^{b} \pm 1.40$ & $42.92^{\mathrm{a}} \pm 2.38$ & 0.003 & Significant & $48.33^{a} \pm 0.97$ \\
\hline & Surgical & $47.85^{\mathrm{a}} \pm 1.63$ & $51.72^{b} \pm 1.17$ & $53.93^{\mathrm{b}} \pm 1.62$ & 0.016 & Significant & $50.77^{a} \pm 0.91$ \\
\hline & $p$-value & 0.302 & 0.515 & $0.000^{*}$ & & & 0.066 \\
\hline \multirow[t]{3}{*}{ Overall Rating (in \%) } & Medical & $78.37^{\complement} \pm 1.14$ & $74.53^{\mathrm{b}} \pm 1.22$ & $68.43^{\mathrm{a}} \pm 1.58$ & 0.000 & Significant & $74.30^{\mathrm{a}} \pm 0.79$ \\
\hline & Surgical & $74.85^{b} \pm 1.29$ & $70.89^{a} \pm 1.68$ & $76.96^{\mathrm{b}} \pm 1.51$ & 0.020 & Significant & $74.31^{a} \pm 0.86$ \\
\hline & $p$-value & $0.043^{*}$ & $0.041^{*}$ & $0.000^{*}$ & & & 0.993 \\
\hline
\end{tabular}

Values are mean \pm Standard Deviation. Mean values along the row (among the hospitals) with different alphabetical superscript indicates a significant different $(p<0.05)$, while the $p$-value of less than 0.05 indicates a significant difference between the hospital services (medical and surgical);

*indicate significant difference

facilities in order to decrease their waiting times and enhance PE for quality of ambulatory care. It has been shown that increased waiting time also affect the overall treatment provided by physicians and other care givers [24]. In UK the national standard or accepted waiting time is $30 \mathrm{~min}$ [25]. In Nigeria, previous studies show that the majority of outpatients wait as long as $80-180$ min or more in the OPDs, and the commonest reason for this long waiting time is the large number of patients as against few health workers $[17,26]$. A study in India obtained average waiting time outside the various OPDs of only $12 \mathrm{~min}$ and $98.52 \%$ of patients were very satisfied with it [13]. The finding that very educated patients, unlike the illiterate ones, are less satisfied with waiting time, could be a reflection of their increased awareness of their rights and privileges because of their level of education and therefore more discerning of the expected quality of healthcare services. The educational status of the respondents was also related to their expectations of the quality of care by the nurses/other health workers. The poorly educated outpatients rated waiting time and quality of care by nurses/other health workers higher than the more educated people, probably because they were not aware of their right to quality services and care. On the other hand, educational status was not significantly associated with patients' rating for OPD environment, doctors' care and responsiveness of care. However, this differs from the findings of Zalmanovitch and Vashdi (2014) who reported that a lower level of education predicates greater responsiveness of care for primary and preventive healthcare than higher level of educational status [27].

The mean overall patient experience rating in this study, though higher than that of similar study in a Federal Medical Centre in Southeast Nigeria (where average satisfaction score of outpatients respondents was 66.8\%), is slightly below $83.0 \%$ obtained in a hospital of similar status (Aminu Kano teaching hospital) in Northern Nigeria [28-30]. The present study showed that employment status, and not level of education, had direct significant association with patients' rating for overall quality of care. Higher proportion of employed and retired outpatients rated the quality of care from the hospitals high. This, to some extent, is at variance with the findings of Arpey, et al. (2017) who in their recent study observed that patients' SES had no impact in the way they are viewed or treated by their physicians [31]. However, our findings agreed with that of Myers, et al. (2006) and Bernheim, et al. (2008) who found that physicians as a group perceive and treat low SES patients 
Table 4 Measure of association between patient experience variables and socioeconomic status of outpatients

\begin{tabular}{|c|c|c|c|c|c|}
\hline \multirow[t]{2}{*}{ SES } & \multirow[t]{2}{*}{ Categories } & \multicolumn{2}{|l|}{ Waiting Time } & \multirow[t]{2}{*}{ Chi-Square } & \multirow[t]{2}{*}{ Linear by Linear Association } \\
\hline & & $\leq 10$ & $>10$ & & \\
\hline \multirow[t]{4}{*}{ Level of Education } & No Formal Education & $21^{\mathrm{a}}(38.9)$ & $33^{\mathrm{a}}(61.1)$ & & $11.215[0.001]^{*}$ \\
\hline & Primary Education & $47^{b}(55.3)$ & $38^{\mathrm{b}}(44.7)$ & & \\
\hline & Secondary Education & $60^{c}(58.3)$ & $43^{\mathrm{C}}(41.7)$ & & \\
\hline & Tertiary Education & $109^{d}(65.7)$ & $57^{d}(34.3)$ & & \\
\hline \multirow[t]{4}{*}{ Employment Status } & Employed & $102^{a}(60)$ & $68^{\mathrm{a}}(40)$ & $6.358[0.95]$ & \\
\hline & Not Employed & $56^{c}(48.7)$ & $59^{\mathrm{C}}(51.3)$ & & \\
\hline & Student & $31^{\mathrm{a}}(63.3)$ & $18^{\mathrm{a}}(36.7)$ & & \\
\hline & Retired & $48^{b}(64.9)$ & $26^{\mathrm{b}}(35.1)$ & & \\
\hline \multirow[t]{2}{*}{ Variable } & Categories & OPD Environment & & Chi-Square & Linear by Linear Association \\
\hline & & $\leq 15$ & $>15$ & & \\
\hline \multirow[t]{4}{*}{ Level of Education } & No Formal Education & $1^{\mathrm{a}}(1.9)$ & $53^{\mathrm{a}}(98.1)$ & & $2.337[0.126]$ \\
\hline & Primary Education & $4^{\mathrm{a}}(4.7)$ & $81^{\mathrm{a}}(95.3)$ & & \\
\hline & Secondary Education & $5^{\mathrm{a}}(4.9)$ & $98^{\mathrm{a}}(95.1)$ & & \\
\hline & Tertiary Education & $12^{\mathrm{a}}(7.2)$ & $154^{\mathrm{a}}(92.8)$ & & \\
\hline \multirow[t]{4}{*}{ Employment Status } & Employed & $14^{\mathrm{a}}(8.2)$ & $156^{\mathrm{a}}(91.8)$ & $4.734[0.192]$ & \\
\hline & Not Employed & $4^{\mathrm{a}}(3.5)$ & $111^{\mathrm{a}}(96.5)$ & & \\
\hline & Student & $2^{\mathrm{a}}(4.1)$ & $47^{\mathrm{a}}(95.9)$ & & \\
\hline & Retired & $2^{\mathrm{a}}(2.7)$ & $72^{\mathrm{a}}(97.3)$ & & \\
\hline \multirow[t]{2}{*}{ Variable } & Categories & Quality of Doctors Services & & Chi-Square & Linear by Linear Association \\
\hline & & $\leq 25$ & $>25$ & & \\
\hline \multirow[t]{4}{*}{ Level of Education } & No Formal Education & $5^{\mathrm{a}}(9.3)$ & $49^{\mathrm{a}}(90.7)$ & & $0.246[0.62]$ \\
\hline & Primary Education & $8^{\mathrm{a}}(9.4)$ & $77^{\mathrm{a}}(90.6)$ & & \\
\hline & Secondary Education & $6^{\mathrm{a}}(5.8)$ & $97^{\mathrm{a}}(94.2)$ & & \\
\hline & Tertiary Education & $13^{\mathrm{a}}(7.8)$ & $153^{\mathrm{a}}(92.2)$ & & \\
\hline \multirow[t]{4}{*}{ Employment Status } & Employed & $13^{b}(7.6)$ & $157^{b}(92.4)$ & $6.706[0.082]$ & \\
\hline & Not Employed & $12^{c}(10.4)$ & $103^{c}(89.6)$ & & \\
\hline & Student & $6^{c}(12.2)$ & $43^{c}(87.8)$ & & \\
\hline & Retired & $1^{\mathrm{a}}(1.4)$ & $73^{\mathrm{a}}(98.6)$ & & \\
\hline \multirow[t]{2}{*}{ Variable } & Categories & Quality of care or Services by & Nurses/other Medical Staff & Chi-Square & Linear by Linear Association \\
\hline & & $\leq 25$ & $>25$ & & \\
\hline \multirow[t]{4}{*}{ Level of Education } & No Formal Education & $3^{\mathrm{a}}(14.3)$ & $18^{\mathrm{c}}(85.7)$ & & $7.132[0.008]^{*}$ \\
\hline & Primary Education & $5^{b}(20.8)$ & $19^{\mathrm{b}}(79.2)$ & & \\
\hline & Secondary Education & $10^{\mathrm{b}}(19.6)$ & $41^{b}(80.4)$ & & \\
\hline & Tertiary Education & $26^{c}(38.2)$ & $41^{\mathrm{a}}(60.3)$ & & \\
\hline \multirow[t]{4}{*}{ Employment Status } & Employed & $13^{\mathrm{a}}(20.3)$ & $51^{\mathrm{a}}(79.7)$ & $5.057[0.536]$ & \\
\hline & Not Employed & $17^{\mathrm{a}}(30.4)$ & $39^{\mathrm{a}}(68.6)$ & & \\
\hline & Student & $6^{a}(40)$ & $9^{a}(60)$ & & \\
\hline & Retired & $9^{a}(31)$ & $20^{\mathrm{a}}(69)$ & & \\
\hline \multirow[t]{2}{*}{ SES } & Categories & Responsiveness & & Chi-Square & Linear by Linear Association \\
\hline & & $\leq 50$ & $>50$ & & \\
\hline \multirow[t]{3}{*}{ Level of Education } & No Formal Education & $18^{\mathrm{a}}(33.3)$ & $36^{\mathrm{a}}(66.7)$ & & $0.569[0.451]$ \\
\hline & Primary Education & $33^{\mathrm{a}}(38.8)$ & $52^{\mathrm{a}}(61.2)$ & & \\
\hline & Secondary Education & $37^{\mathrm{a}}(35.9)$ & $66^{\mathrm{a}}(64.1)$ & & \\
\hline
\end{tabular}


Table 4 Measure of association between patient experience variables and socioeconomic status of outpatients (Continued)

\begin{tabular}{|c|c|c|c|c|c|}
\hline \multirow[t]{2}{*}{ SES } & \multirow[t]{2}{*}{ Categories } & \multicolumn{2}{|l|}{ Waiting Time } & \multirow[t]{2}{*}{ Chi-Square } & \multirow[t]{2}{*}{ Linear by Linear Association } \\
\hline & & $\leq 10$ & $>10$ & & \\
\hline & Tertiary Education & $52^{\mathrm{a}}(31.3)$ & $114^{\mathrm{a}}(68.7)$ & & \\
\hline \multirow[t]{4}{*}{ Employment Status } & Employed & $55^{\mathrm{a}}(32.4)$ & $115^{\mathrm{a}}(67.6)$ & $0.675[0.879]$ & \\
\hline & Not Employed & $42^{\mathrm{a}}(36.5)$ & $73^{\mathrm{a}}(63.5)$ & & \\
\hline & Student & $18^{\mathrm{a}}(36.7)$ & $31^{\mathrm{a}}(63.3)$ & & \\
\hline & Retired & $25^{\mathrm{a}}(33.8)$ & $49^{\mathrm{a}}(66.2)$ & & \\
\hline \multirow[t]{2}{*}{ Variable } & Categories & Overall Rating (\%) & & Chi-Square & Linear by Linear Association \\
\hline & & $\leq 70$ & $>70$ & & \\
\hline \multirow[t]{4}{*}{ Level of Education } & No Formal Education & $17^{a}(31.5)$ & $37^{a}(68.5)$ & & $1.312[0.252]$ \\
\hline & Primary Education & $32^{\mathrm{a}}(37.6)$ & $53^{\mathrm{a}}(62.4)$ & & \\
\hline & Secondary Education & $33^{\mathrm{a}}(32)$ & $70^{\mathrm{a}}(68)$ & & \\
\hline & Tertiary Education & $68^{\mathrm{a}}(41)$ & $98^{\mathrm{a}}(59)$ & & \\
\hline \multirow[t]{4}{*}{ Employment Status } & Employed & $60^{b}(35.3)$ & $110^{\mathrm{b}}(64.7)$ & $8.711[0.033]^{*}$ & \\
\hline & Not Employed & $51^{\mathrm{c}}(44.3)$ & $64^{c}(55.7)$ & & \\
\hline & Student & $21^{c}(42.9)$ & $28^{\mathrm{c}}(57.1)$ & & \\
\hline & Retired & $18^{\mathrm{a}}(24.3)$ & $56^{\mathrm{a}}(75.7)$ & & \\
\hline
\end{tabular}

Each superscript letter denotes a subset of Variable categories whose row proportions do not differ significantly from each other at the .05 level, ()-\%, [ - $p$-value *indicate significant difference

differently from those of higher SES [32, 33]. Maharlouei, et al. (2017) had also reported on how the overall patient experience was associated with different SES [34].

The limitations of this study include its inability to capture all the domains of patient care in the hospitals. It was restricted to measures of outpatient or ambulatory healthcare services. Thus, the findings cannot be generalized to include that of admitted patients. Another limitation is the fact that the data collection instrument used both coding and tick-box approaches, which could have led to some confusion for the enumerators/interviewers. However, the thorough training that was undertaken by the interviewers before field work ensured that they understood the response formats and could navigate between coding and tick-box approaches. Coding framework from previous studies was adapted [18-20] and pretested in the study area, hence the possible occurrence of bias is potentially insignificant. Although, the pre-test showed that the instrument worked well within the study context, it is recommended that a uniform coding approach be used in future studies.

\section{Conclusion}

The study revealed how employment status was significantly associated with overall patient experience rating of the quality of care for ambulatory (outpatients) healthcare services in Nigeria hospitals. It also showed that level of education significantly impacted on how outpatients perceived waiting time and quality of care from nurses and other care givers in the hospital.
Further study will be required to assess other drivers of the rating of quality of care, the provider-side influences on quality of care and the effect of socio-economic status on inpatients type of healthcare services in the hospitals.

\section{Recommendations}

The study has underscored the need to put into consideration the socioeconomic status of patients in the course of providing healthcare services for a given population.

\section{Supplementary information}

Supplementary information accompanies this paper at https://doi.org/10. 1186/s12913-020-05332-0.

Additional file 1. Patient Experience Questionnaires (PEQ) on Quality of Healthcare Services in Nigeria Teaching Hospitals.

Additional file 2. Informed Consent Form for patients.

Additional file 3. Samples of Ethical Approval for the Study.

\section{Abbreviations}

ESUTH: Enugu State University Teaching Hospital; FETHA: Federal University Teaching Hospital; LMICs: Low- and middle-income countries; MOPD: Medical outpatient department; OPD: Outpatient department; PE: Patient experience; PEQ: Patient experience questionnaire; SES: Socioeconomic status; SOPD: Surgical outpatient department; UNTH: University of Nigeria Teaching Hospital

\section{Acknowledgments}

We are most grateful to the management and medical record departments of all the participating hospitals for their assistance. 


\section{Authors' contributions}

HA conceptualized and designed the study and coordinated all the research activities including the drafting of the manuscript. OA coordinated the data collection. $\mathrm{OO}$ and $\mathrm{IO}$ contributed to the design of the study and oversaw the supervision the study. CN analyzed and interpreted the data. All authors reviewed the study findings, read and approved the manuscript before submission.

\section{Funding}

The data collection stage of the study was funded by the corresponding authors. The individual authors' time on the research design, data collection, analysis, interpretation and report writing were funded by each authors, respectively.

\section{Availability of data and materials}

Data-sets used and analyzed for the study are available and may be released by the corresponding author on reasonable request.

\section{Ethics approval and consent to participate}

Permission for this study was obtained from Nigeria Federal Ministry of Health, and approvals were obtained from respective Health Research Ethical Committees of all the three participating Teaching hospital:

a) University of Nigeria Teaching Hospital Health Research Ethics Committee, NHREC/05/01/2008B-FWA00002458-1 RB00002323;

b) Federal Teaching Hospital Health Research Ethics Committee, FETHA/REC/ VOL1/2017/479; REC PROTOCOL NUMBER 14/02/2017-24/02/2017;

c) Enugu State University Teaching Hospital Parklane, ESUTHP/C-MAC/RA/ 034/175

Informed written consent were obtained from all patients that participated in the study. For those patients who were below 18 years of age, parental written consent were obtained.

\section{Consent for publication}

Not applicable.

\section{Competing interests}

The authors declare that they have no competing interests.

\section{Author details}

${ }^{1}$ Health Economics and Policy Research Unit, Department of Health Services, Alex Ekwueme Federal University Ndufu-Alike Ikwo, Ikwo, Ebonyi State, Nigeria. ${ }^{2}$ Department of Health Administration \& Management, Faculty of Health Sciences, College of Medicine, University of Nigeria, Enugu Campus, Enugu, Nigeria. ${ }^{3}$ Primary Health Development Agency, Ministry of Health, Enugu, Ebonyi State, Nigeria. ${ }^{4}$ Department of Mathematics/Computer Sciences/Statistics \& Informatics, Alex Ekwueme Federal University Ndufu-Alike Ikwo, Enugu, Nigeria.

Received: 13 November 2019 Accepted: 17 May 2020

Published online: 26 May 2020

\section{References}

1. Eneji MA, Dickson VJ, Onabe BJ. Health care expenditure; health status and national productivity in Nigeria (1999-2012). J Econ Int Finance. 2013;5(7): 258-73.

2. Masoompour MS, Petramfar P, Farhadi P, Mahdaviazad H. Five-year trend analysis of capacity utilization measures in a teaching hospital 2008-2014. Shiraz E-Med J. 2015;16(2):ez1176.

3. Chansky B, Garner C, Raichoudhary R. Measuring output and productivity in private hospitals [Internet]. Cambridge: National Bureau of Economic Research; 2013. http://www.nber.org/chapters/c13096.pdf

4. Jenkinson C, Coulter A, Bruster S. The Picker Patient Experience Questionnaire: development and validation using data from in-patient surveys in five countries. Int J Qual Health Care. 2002;14(5):353-8.

5. Wolf JA, Niederhauser V, Marshburn D, LaVela SL. Defining patient experience. Patient Exp J. 2014;1 (1,3):7-19.

6. Staniszewska S, Boardman F, Gunn L, Roberts J, Clay D, Seers K, Brett Avital L, Bullock I, O'Flynn N. The Warwick patient experience franework: patient-based evidence in clinical quideline. Int J Qual Health Care. 2014; 26(2):151-7.
7. LaVela SL, Gallan AS. Patient experience, evaluation and measurement of patient experience. Patient Exp J. 2014;1 (1, 5):28-56.

8. Rama M, Kanagaluru SK. A study on the satisfaction of patients with referrence to hospital services. Int J Bus Econ Manag Res. 2011;1(3):15-25.

9. Iftikhar A, Allah N, Shaduiullah K, Habibullah K, Muhammad AR, Muhammad HK. Predictor of patient satisfaction. Gomal J Med Sci. 2011;9(2):183-1888.

10. Dunsch F, Evans DK, Macis M, Wang Q. Bias in patient satisfaction surveys: a threat to measuring healthcare quality. BMJ Glob Health. 2018;3(2):e000694. https://doi.org/10.1136/bmjgh-2017-000694.

11. Manary MP, Boulding W, Staelin R, Glickman SW. The patient experience and health outcomes. N Engl J Med. 2013;368:201-3.

12. Ashton F, Hamid K, Sulieman S, Eardley W, Baker P. Factors influencing patient experience and satisfaction following surgical management of ankle fractures. Injury J. 2017:48(4):960-5.

13. Patel R, Patel HR. A study on waiting time and out-patient satisfaction at Gujarat medical education research society hospital, Valsad, Gujarat, India. Int J Community Med Public Health. 2017;4(3):857-63.

14. Aiken $L H$, Sermeus $W$, Heede KV, Sloane DM, Busse R, McKee M, Bruynee $L$, Rafferty AM, Griffiths P, Moreno-Casbas MT, Tishelman C, Scott A, Brzostek T, Kinnunen J, Schwendimann R, Heinen M, Zikos D, Sjetne IS, Smith HL, Kutney-Lee A. Patient safety, satisfaction, and quality of hospital care: cross sectional surveys of nurses and patients in 12 countries in Europe and the United States. BMJ. 2012;344:e1717. https://doi.org/10.1136/bmj.e1717.

15. Mejabi OV, Olujide JO. Dimensions of hospital service quality in Nigeria. Eur J Soc Sci. 2008:5(4):141-59.

16. Ofilli AN, Ofowve CE. Patient's assessment of efficiency of services at a teaching hospital in a developing country. Ann Afr Med. 2005;4:150-3.

17. Oche MO, Adamu H. Determinants of patient waiting time in the general outpatient department of a tertiary health institution in the North Western Nigeria. Ann Med Health Sci Res. 2013;3(4):588-92.

18. Garrat AM, Bjaertnes A, Krogstad U, Gulbrandsen P. The Outpatient Experience Questionnaire (OPEQ): data quality, reliability and validity in patients attending 52 Norwegian hospitals. BMJ J. 2016;13:433-7.

19. Thompson AJ, Sutton M, Payne K. Preference-based assessments estimating joint health condition utility values. Value Health. 2019;22:482-90. https:// doi.org/10.1016/j.jval.2018.09.2843.

20. Petersen GS, Knudsen JL, Vinter AM. Cancer patients' preferences of care within hospitals: a systematic literature review. Int J Qual Health Care. 2015; 27(5):384-95. https://doi.org/10.1093/intghc/mzv059.

21. Wong ELY, Coulter A, Hewitson P, Cheung AWL, Yam CHK, Lui S, Tam WS, Yeoh E. Patient experience and satisfaction with inpatient aservices: development of short form survey instrument measuring the core aspect of inpatient experience. PLoS One. 2015;10(4):1-12.

22. Mujasi PN, Asbu EZ, Puig-Junoy J. How efficient are referral hospitals in Uganda? A data envelopment analysis and Tobit regression approach. BMC Health Serv Res. 2016;8(16):230.

23. Doyle C, Lennox L, Bell D. A systematic review of evidence on the links between patient experience and clinical safety and effectiveness. Br Med J Open. 2013;3(1):1-18.

24. Pandit A, Varma L, Amruta P. Impact of OPD waiting time on patient satisfaction. Int Educ Res J. 2016;2(8):86-90.

25. Bleustein C, Rothschild DB, Valen A, Valatis E, Schweitzer L, Jones R. Wait time, patient satisfaction, and the perception of care. Am J Manag Care. 2014;20(5):393-400.

26. Yeboah $E$, Thomas M. A cost effective way of reducing outpatient clinic waiting times: how we did it. Internet J Healthc Adm. 2009;7(1):1-4.

27. Zalmanovitch, Y. and Vashdi, D. R. (2014). The relationship between socioeconomic factors and responsiveness gaps in primary, preventive and health promotion services. Health Expect. doi: https://doi.org/10.1111/hex. 12238. Retrieved 22 Oct 2018.

28. Ameh N, Sabo B, Oyefabi MO. Application of queuing theory to patient satisfaction at a tertiary hospital in Nigeria. Niger Med J. 2013;54:64-7.

29. Iloh GUP, Ofoedu JN, Njoku PU, Odu FU, Ifedigbo CV, Iwuamanam KD. Evaluation of patients' satisfaction with quality of care provided at the National Health Insurance Scheme clinic of a tertiary hospital in southeastern Nigeria. Niger J Clin Pract. 2012;15(4):469-74.

30. Iliyasu Z, Abubakar IS, Lawan UM, Gajida AU. Patients' satisfaction with services obtained from Aminu Kano Teaching Hospital, Northern Nigeria. Niger J Clin Pract. 2010;13(4):371-8.

31. Arpey, N. C., Gaglioti, A. H., Rosenbau, M. E. How socioeconomic status affects patient's perceptions of healthcare: a qualitative study. J Prim Care 
Community Health; 2017. doi:https://doi.org/10.1177/2150131917697439. Retrieved 20 Oct 2018.

32. Meyers DS, Mishori R, McCann J. Primary care physicians' perceptions of the effect of insurance status on clinical decision making. Ann Fam Med. 2006; 4(2):399-402.

33. Bernheim SM, Ross JS, Krumbolz HM, Bradley EH. Influence of patients' socioeconomic status on clinical management decisions: a qualitative study. Ann Fam Med. 2008;6(1):53-9.

34. Maharlouei N, Akbari M, Akbari M, Lankarani KB. Socioeconomic status and satisfaction with public healthcare system in Iran. Int J Community Based Nurs Midwifery. 2017;5(1):22-9.

\section{Publisher's Note}

Springer Nature remains neutral with regard to jurisdictional claims in published maps and institutional affiliations.

Ready to submit your research? Choose BMC and benefit from:

- fast, convenient online submission

- thorough peer review by experienced researchers in your field

- rapid publication on acceptance

- support for research data, including large and complex data types

- gold Open Access which fosters wider collaboration and increased citations

- maximum visibility for your research: over $100 \mathrm{M}$ website views per year

At $\mathrm{BMC}$, research is always in progress.

Learn more biomedcentral.com/submissions 